\title{
The Relationship between Personality and Job Satisfaction among Employees in Libyan Oil and Gas Company
}

\author{
Haliza Mohd Said ${ }^{1}$, Mohamed KhamisAbukraa ${ }^{2}$, Roslan Mohd Rose ${ }^{3}$ \\ ${ }^{1}$ Unitar International University, 3-01A, Level 3, Jalan SS6/3, Kelana Jaya, 47301 Petaling Jaya, Selangor, Malaysia \\ ${ }^{2}$ Unitar International University, 3-01A, Level 3, Jalan SS6/3, Kelana Jaya, 47301 Petaling Jaya, Selangor, Malaysia \\ ${ }^{3}$ Unitar International University, 3-01A, Level 3, Jalan SS6/3, Kelana Jaya, 47301 Petaling Jaya, Selangor, Malaysia
}

\begin{abstract}
Job satisfaction has been an important topic in organizational researches; it is one of the most broadly researched subject in industrial/organizational psychology, due to its many effects on the overall organizational effectiveness. Employee's job satisfaction is a good indicator of the organizational effectiveness, and it is influenced by organizational and dispositional factors. There are many factors that can influence employee level of job satisfaction; personality is one of the many factors that suggested being as a source of job satisfaction since that some individuals are a subject to negative affectivity, while others are predisposed to a positive affectivity.However, the extent of the association has not been investigated comprehensively in the context of the Libyan oil and gas company. Therefore, the purpose of this study aims to examinethe effect of personality dimensions on job satisfaction of employees in Libyan oil and gas company. A cross-sectional design was used to address the research objective. The sample consisted of 200 employees working at the company main office in Tripoli. The collected data were analyzed using correlation coefficient and regression analysis. The result shows that the personality dimensions of openness to experience, conscientiousness, extraversion, agreeableness and neuroticism of employees in the company had significant positive relationships with their job satisfaction.
\end{abstract}

Keywords: Personality traits, Job satisfaction, Oil and gas, Openness to Experience, Conscientiousness, Extraversion, Agreeableness, Neuroticism

\section{INTRODUCTION}

The recent years have seen a remarkable development in social sciences; this development has emerged clearly in the field of organizational behavior and the study of human resources management, a study that focused on the employee's development as an important part of organization resources (Tett\& Meyer 1993). Hence, it is clear that human resource play an important role in the organization performance by trying to keep employees satisfied (Oshagbemi, 2003). Managers as well as employers realize that for their organization to achieve best effectiveness and optimal performance, it depends in a part on the employee's level of job satisfaction. In all levels of the organization, the employees' full potential is needed and that emphasize on the importance of their being satisfied (Kreitner\&Kinicki, 1998). This is definitely important in the oil and gas industry in Libya since that this field of industry requires employees to be fully concentrated which will generate stress at work.

Job satisfaction has been broadly studied and in the recent decades it has become an important objective for corporate as well as researchers and one of the most frequently studied work attitudes (Currivan, 1999; Lund 2003). According to Cranny, Smith \& Stone, Job satisfaction is a reaction to a job that is stemmed from the assessment of a job occupant of actual outcomes with the required outcomes (Cranny, Smith \& Stone, 1992). Dessler (1978) on the other hand, described job satisfactionas the degree of needs satisfaction that resulting from and or experienced on the job. Researchers have sought to explain job satisfaction and its predictors since it is related with other key factors of the organizational behavior such as turnover, absenteeism, performance, productivity, workplace and organizational citizenship behavior, in addition its prediction of employee behavior and subjective wellbeing (Robbins \& Judge, 2007; Peter \&Siegrist 2000; Bosma, Jonge).

Many researches have been put into different viewpoints and theories on factors that influence the feeling of satisfaction with a job. Personality has been considered as a popular area of study and an important factor when it comes to influencing the experience of job satisfaction ((Judge, Heller, \& Mount, 2002; Lounsbury, Sundstrom, Gibson, Drost, \& Hamrick, 2003; Petrides, Jackson \& Cotter, 2002; Judge, Heller \& Klinger 2008; Bruk-Lee,

${ }^{1}$ Corresponding Author: lizasaid@ unitar.my 
Khouty, Nixon, Goh, \& Spector, 2009). According to Locke (1976) personality has been considered as one among the many factors that act as a source of job satisfaction.

As stated in the prevailing management proverbs, workers who are happy tend to be more satisfied. Correspondingly, satisfied workers will be more productive and committed to their job than their counterparts who are dissatisfied (Robbins \& Judge, 2011). Satisfied and motivated employees can produce superior performance which would allow organizations to reach competitive levels of qualitywhich on turn leads to increase profits. For that reason, this study was conducted in order to understand better the relationshipbetween personality traits and job satisfaction.

Employees considered as the most important element of an organization, and a key factor in its productivitythat can determine the success of an organization in an environment of competitiveness (Fiorita, Bozeman, Young \&Meurs, 2007). There are many factors that influence work style of employees. These factors affect their job performance, attitude towards work and productivity. Therefore, job satisfaction is an important area in organizational studies since it has an effect on the overall well-being of the organization. The degree of employee's satisfaction will reflect in their willingness to achieve job tasks which contribute in improving their organization performance. Hence, for organizations to remain competitive it needs to develop strategies that would help to increase the employee's satisfaction, retention level and reduce the turnover rate, because in a continuous competitive environment knowledgeable and experienced people are needed to achieve success. Therefore, the level of job satisfaction and employee retention is of great importance since it is vital factor which affect the stability and continuity of firms(Benko\& Weisberg, 2007; Becker, 2007).

In an organization, satisfaction at work or job satisfaction appears to be what employee's desire to have in their work place (Oshagbemi, 2003), and that defines whether employees intend to leave or stay which always becomes the big question for any company. Job satisfaction has an impact on the overall well-being of any organization, therefore it is considered as a significant topic of organizational research that needs an ongoing basis for study since it is an important requirement for organizations that help to gain excellence in their operations.

Job satisfaction in the workplace has received a considerable attention due to its association with many employee attitudes and behaviors. It includes the feelings and attributes that consist with people towards their work. According to some researchers (Scott andTaylor, 1985; Brooke \& Price, 1989; Meyer, Allen, \& Smith, 1993; Buck \& Watson, 2002) job satisfaction is related with absenteeism and turnover intention. Likewise, (Ostroff, 1992; Buitendach\& De Witte, 2005) stated that job satisfaction is associated with motivation and performance. In contrast, other researchers such (Certin, 2006; Cohrs, Abele, \&Dette, 2006; Rayton, 2006) indicated that it has a correlation with organizational citizenship and commitment. The positive and meaningful attitudes towards one's job will mean satisfaction at work, while negative attitudes will indicate to dissatisfaction at work. Satisfaction at work will give employees the motivation to accomplish the work tasks properly and more accurately moreover be more creative and innovative, which leads to better performance for organizations and increases in profit.

Hence, in order to increase or improve employee's level of satisfaction, the factors that influence job satisfaction should be identified. Many researchers pointed to various factors that affect job satisfaction, among these factors the Big Five personality dimensions or the personality traits of employees which identified as important factors that form the employees' job satisfaction. Studies propose that the differences in the level of satisfaction amongst employees could be a consequence of employee's personality, since that some of personality traits and satisfaction was found to be strongly associated, whilst others found to be strongly associated with dissatisfaction (Judge, Heller, \& Mount, 2002; Furnhama, Petridesa, Jackson, \& Cotter, 2002).

Therefore, it is worthwhile that there will be studies which draws attention to the category of employees in oil and gas companies, to measure their attitudes, reactions and their administrative, psychological and social working conditions and how that impact on their work performance. Thus, this will help the human resource management to measure the level of satisfaction among employees and their intention to leave or to stay. From here, the problem addressed in this study is to illustrate whether the five factor model of personality has an impact on the level of job satisfaction of employees in Libyan Oil and Gas Company

\section{DAta ANALYSIS}

\subsection{Descriptive Analysis}

This section discusses the descriptive statistics based on the respondent profile. 
There are a total 200 questionnaire distributed among the potential respondents for data collection in Libya. Only 177 returned questionnaires were usable. The analysis starts with the demographic analysis and the highlights of the results are presented below.

\subsection{Gender}

Gender was taken into account as a medium of profile to investigate on the work profile of the employees working in different oil industries in Libya. From Table (2.1), it can be seen that there are total 145 male respondents (81.9\%) and only 32 female respondents (18.1\%). This shows that in Libya, job opportunities for female respondents are less in the oil and gas industry compare to males as this particular industry needs physical hardship.

Table 2.1: Distribution of Respondents by Gender

\begin{tabular}{|c|c|c|}
\hline & Frequency & Percent \\
\hline Male & 145 & 81.9 \\
\hline Female & 32 & 18.1 \\
\hline Total & 177 & 100.0 \\
\hline
\end{tabular}

\subsection{Age}

Based on the demographic results Table (2.2), it was found that most of the respondents were of young and middle aged. From all the respondents participated, majority of them aged between 31 to 40 years old (46.9\%) and followed by $41-50$ years old $(27.7 \%)$ and 51 and above years old (13\%). Only 22 respondents are 30 or less than years old which contributes only (12.4\%). It is concluded from the age as a demographic profile of respondents that the middle aged peoples are mostly hired to work in the oil and gas industry in Libya as experience is very important.

Table 2.2: Distribution of Respondents by Age

\begin{tabular}{|c|c|c|}
\hline & Frequency & Percent \\
\hline 30 or less than & 22 & 12.4 \\
\hline $31-40$ & 83 & 46.9 \\
\hline $41-50$ & 49 & 27.7 \\
\hline 51 and above & 23 & 13.0 \\
\hline Total & 177 & 100.0 \\
\hline
\end{tabular}

\section{WORK POSITION}

Consistent with the findings from the academic qualifications, it is obvious that majority of the respondents are working as executives $(86.4 \%)$ while only 24 respondents or $(13.6 \%)$ of the respondents are non-executives (Table 2.3)

Table 2.3: Distribution of Respondents by Work Position

\begin{tabular}{|c|c|c|}
\hline & Frequency & Percent \\
\hline Executive & 153 & 86.4 \\
\hline Non-executive & 24 & 13.6 \\
\hline Total & 177 & 100.0 \\
\hline
\end{tabular}

\subsection{Job Tenure}

This study has also explored the job tenure as a demographic profile. (Table 2.4) shows that majority of the employees in Libyan oil company are mid-level employees. Total 106 respondents $(59.9 \%)$ fall in the category between 5 and 10 years followed by 40 respondents (22.6\%) fall between 11 and 15 years. Besides, (8.5\%) of the respondents are having more than 15 years of experiences whereas only $(9 \%)$ of the respondents are having less than 5 years of experience. The finding supports the job tenure category discussed above. 
American Research Journal of Business and Management, Volume 1, Issue2, 2015

ISSN 2379-1047

Table 2.4: Distribution of Respondents by Job Tenure

\begin{tabular}{|c|c|c|}
\hline & Frequency & Percent \\
\hline Less than 5 years & 16 & 9.0 \\
\hline Between 5 \& 10 years & 106 & 59.9 \\
\hline Between 11 \& 15 years & 40 & 22.6 \\
\hline More than 15 years & 15 & 8.5 \\
\hline Total & 177 & 100.0 \\
\hline
\end{tabular}

\subsection{Monthly Income}

In terms of income level, most of the respondents earns between LD 1000 to LD 3000 (total 127 respondents) while 12 respondents earns more than LD 3000 a month (Table 2.5). Rest 38 respondents earn less than LD 1000 a month.

Table 2.5: Distribution of Respondents by Monthly Income

\begin{tabular}{|c|c|c|}
\hline & Frequency & Percent \\
\hline Less than 1000 LD & 38 & 21.5 \\
\hline 1001 LD - 2000 LD & 87 & 49.2 \\
\hline 2001 LD - 3000 LD & 40 & 22.6 \\
\hline More than 3000 LD & 12 & 6.8 \\
\hline Total & 177 & 100.0 \\
\hline
\end{tabular}

\subsection{Pearson Correlation Test}

Pearson correlation test was performed to ensure whether the variables are inter correlated. This process ensures that one variable is not reflective of other variable (Bentler, 1995). The Pearson correlation also demonstrates the relationship among all dependent and independent variables (Nunnally\&Berstein, 1994). The range of variation for correlation is between -1 and 1 , and p-value should be less than 0.05 to indicate significant relationships (Hair et al., 2010; Kothari, 2004; Neuman, 2007).

Referring to (Table 2.6), all the variables have significant and positive relationships with job satisfaction. Among the independent variables, the highest correlations refer to Conscientiousness (0.457) followed by Agreeableness (0.454), Openness to Experience (0.416), Extraversion (0.253) and Neuroticism (0.253). So, we can say that the variables may have positive relationship with each other. Thus, this ensures that there is a strong relationship exists between the variables. This also confirms to proceed with further analysis.

Table 2.6: Pearson Correlation

\begin{tabular}{|l|l|l|l|l|l|l|l|}
\hline & & $\begin{array}{l}\text { Job } \\
\text { Satisfaction }\end{array}$ & $\begin{array}{l}\text { Openness to } \\
\text { Experience }\end{array}$ & $\begin{array}{l}\text { Conscientious } \\
\text { ness }\end{array}$ & $\begin{array}{l}\text { Extraversio } \\
\mathrm{n}\end{array}$ & $\begin{array}{l}\text { Agreeablenes } \\
\mathrm{s}\end{array}$ & $\begin{array}{l}\text { Neurotici } \\
\mathrm{sm}\end{array}$ \\
\hline $\begin{array}{l}\text { Job } \\
\text { Satisfa } \\
\text { ction }\end{array}$ & $\begin{array}{l}\text { Pearson } \\
\text { Correlatio } \\
\mathrm{n}\end{array}$ & 1 & $.416^{* *}$ & $.457^{* *}$ & $.253^{* *}$ & $.454^{* *}$ & $.253^{* *}$ \\
\hline & $\begin{array}{l}\text { Sig. } \\
\text { tailed) }\end{array}$ & & .000 & .000 & .001 & .000 & .001 \\
\hline & $\mathrm{N}$ & 177 & 177 & 177 & 177 & 177 & 177 \\
\hline
\end{tabular}

Correlation is significant at the 0.01 level (2-tailed).

\subsection{Multiple Regression Analysis}

The result of regression analysis in this section is based on following tables (2.7.1), (2.7.2) and (2.73).

Results from the (Table 2.7.1) indicate that, $69.1 \%$ of variance was explained by these five dimensions of personality $\left(\mathrm{R}^{2}=.691\right)$. Moreover, the substantial "F" statistic of 14.039 and significance of .000 (Table 2.7.2) lead us to be confident that there is a very strong relationship between these five factors (openness to experience, conscientiousness, extraversion, agreeableness and neuroticism) that significantly influence job satisfaction among the employees working in oil and gas company in Libya. 
Table 2.7.1: Model Summary

\begin{tabular}{|c|c|c|c|c|}
\hline Model & R & R Square & Adjusted R Square & Std. Error of the Estimate \\
\hline 1 & $.739^{\mathrm{a}}$ & .691 & .670 & .42229 \\
\hline
\end{tabular}

a. Predictors: (Constant), Neuroticism, Agreeableness, Extraversion, Openness to Experience, Conscientiousness.

Table 2.7.2: ANOVA $^{a}$

\begin{tabular}{|c|c|c|c|c|c|c|}
\hline & Model & $\begin{array}{c}\text { Sum of } \\
\text { Squares }\end{array}$ & df & $\begin{array}{c}\text { Mean } \\
\text { Square }\end{array}$ & F & Sig \\
\hline & Regression & 12.518 & 5 & 2.504 & 14.039 & $.000^{\mathrm{b}}$ \\
\hline 1 & Residual & 30.494 & 171 & .178 & & \\
\hline & Total & 43.012 & 176 & & & \\
\hline
\end{tabular}

a. Dependent Variable: Job Satisfaction

b. Predictors: (Constant), Neuroticism, Agreeableness, Extraversion, Openness to Experience, Conscientiousness.

Finally, from the coefficient analysis (Table 2.7.3), it can be summarized that openness to experience, conscientiousness, extraversion, agreeableness and neuroticism plays a significant role in job satisfaction among the employees working in oil and gas company in Libya. From the findings, it seems that the highest beta coefficient was obtained by the factor openness to experience (0.322) followed by Agreeableness (0.229), Extraversion (0.201), Neuroticism (0.178) and Conscientiousness (0.137) when Job Satisfaction is predicted for.

Table 2.7.3: Coefficients $^{a}$

\begin{tabular}{|c|c|c|c|c|c|c|}
\hline & Model & \multicolumn{2}{|c|}{$\begin{array}{c}\text { Unstandardized } \\
\text { Coefficients }\end{array}$} & $\begin{array}{c}\text { Standardized } \\
\text { Coefficients }\end{array}$ & $\mathrm{t}$ & Sig. \\
\hline & & $\mathrm{B}$ & Std. Error & Beta & & \\
\hline & (Constant) & 1.725 & .289 & & 5.976 & .000 \\
\hline & $\begin{array}{c}\text { Openness to } \\
\text { Experience }\end{array}$ & .322 & .083 & .322 & 1.475 & .000 \\
\hline 1 & Conscientiousness & .137 & .081 & .137 & 1.703 & .001 \\
\hline & Extraversion & .201 & .054 & .201 & .026 & .000 \\
\hline & Agreeableness & .229 & .074 & .229 & 2.825 & .000 \\
\hline & Neuroticism & .178 & .037 & .178 & 2.608 & .009 \\
\hline
\end{tabular}

Dependent Variable: Job Satisfaction.

\section{ConClusion}

This research was aimed to investigate the relationship between the personality traits and job satisfaction among the employees working in oil and gas company in Libya. Specifically, the research was conducted using quantitative data where a set of adapted questionnaire was utilized to collect data from the respondents in Libya. The proposed framework was assessed based on five major personality components, namely openness to experience, conscientiousness, extraversion, agreeableness and neuroticism. The dependent variable for this study was job satisfaction.

Results showed a significant and positive relationship between all components of personality (Openness to Experience, Conscientiousness, Extraversion, Agreeableness, Neuroticism and Job satisfaction, with the highest impact being from Openness to Experience, and the lowest was from Conscientiousness.

The conclusion of this study is summarized from various perspectives. Researchers have noted that identifying and understanding the personality dimensions is vital for any organizations. This is due to the fact that if employees are satisfied with their jobs, the performance of the entire organization will be affected as employees are the main drivers for any organizations. Through this research, a meaningful framework has been established to keep abreast with the aspiration and the findings will facilitate relevant agencies concerned in formulating policies or strategies and even remedial actions required to strengthen the Libyan oil and gas industry in building a well-rounded human 


\section{American Research Journal of Business and Management, Volume 1, Issue2, 2015 ISSN 2379-1047}

capital. The findings of this research do indicate that elements in the framework significantly show a high degree of influence on employee job satisfaction.

\section{REFERENCES}

[1] Aamir S., Sidra H., Hira A. (2013). Study to Explore the Impact of Personality Traits on Employee Turnover in Public and Private Sector. Middle-East Journal of Scientific Research 16 (9): 1249-1254.

[2] Ader, H. J. (2008). Advising on research methods: a consultant's companion. In Ader, H. J., \& Mellenbergh, G. J. (Eds.), Missing Data (pp. 305-332). Huizen, the Netherlands: Johanes van Kessel Publishing.

[3] Alina, I.P. \&\& Robin, S. 2008, "Human resources management practices and workers' job satisfaction", International jornal of manpower, vol. 29, no. 7, pp. 651-667.

[4] Bentler, P. M. (1995). Multivariate analysis with latent variables: Causal modelling. Annual Review of Psychology, 31, 419-456.

[5] Colqnitt, J. A., Bedell, M. D., \& Baldwin, T. T. (1999). The role of ability and conscientiousness in interdependent contexts: More benefits for the less able and less willing? Manuscript submitted for publication.

[6] Creswell, J.W. 2004, Research Design Qualitative, Quantitative, and Mixed Methods Approaches, 3rd edn, Sage Publication, California.

[7] Cronbach, L. J. (1951). Coefficient alpha and the internal structure of tests. Psychometrika, 16(3), 297-334.

[8] Davey, A., \& Savla, J. (2010). Statistical power analysis with missing data: a structural equation modeling approach. New York: Routledge Taylor \& Francis Group.

[9] Donohue, S. M., \& Heywood, J. S. (2004). Job satisfaction and gender: an expanded specification from the NLSY. International Journal of Manpower, 25(2), 211-238.

[10] Furnham, A., Eracleous, A., \& Chamorro-Primuzic, T. (2009). Personality, motivation and job satisfaction: Hertzberg meets the Big Five. Journal of Managerial Psychology, 24(8), 765-779.

[11] Gaertner, S. (2000). Structural determinants of job satisfaction and organizational commitment in turnover models. Human resource management review, 9(4), 479-493.

[12] Gosling, S.D., Rentfrow, P. J., \& Swann Jr., W. B. (2003). A very brief measure of the Big-Five personality domains. Journal of Research in Personality, 37, 504-528.

[13] Hair, J. F., Black, W. C., Babin, B. J., \& Anderson, R. E. (2010). Multivariate Data Analysis: A Global Perspective (7th Global ed.). Upper Saddle River: Pearson Prentice-Hall.

[14] Judge, T. A., Heller, D., \&klinger, R. (2008). The dispositional sources of job satisfaction: A comparative test. Applied Psychology: An International Review, 57(3), 361-372.

[15] Judge, T. A., Heller, D., \& Mount, M. K. (2002). Five-factor model of personality and job satisfaction: A meta-analysis. Journal of Applied Psychology, 87(3), 530-541.

[16] Kothari, C. R. (2004). Research Methodology: Methods and Techniques (2ndedn.). New Delhi: New Age International Publishers.

[17] Kumar, K., \&Bakhshi, A. (2010). The Five Factor Model of Personality: Is there any Relationship? Humanities and Social Sciences Journal, 5(1), 25-34.

[18] Kumari, G., Joshi, G., \& Pandey, K. M. (2014). Analysis of Factors Affecting Job Satisfaction of the Employees in Public and Private Sector. International Journal of Trends in Economics Management and Technology, 3(1), $232-238$.

[19] LavandaCleare. (2013). Personality as a Predictor of Job Satisfaction: Study of the Relationship between Personality and Job Satisfaction amongst Workers in the Bahamas. Journal of Management Research ISSN 1941-899X, Vol. 5, No. 3.

[20] Long, A. (2005). Happily ever after? A study of job satisfaction in Australia. The Economic Record, 81, 303-321.

[21] Lund, D.B. (2003). Organizational culture and job satisfaction. Journal of Business and Industrial Marketing. 18 (3), 219 36.

[22] McAdams, D. P. (2006). The Person: A new introduction to personality psychology. Hoboken, NJ: John Wiley \& Sons.

[23] McCrae, R. R., \& Costa P. T,, Jr. (2003). Personality in adulthood. 2nd edition. New York: Guilford Press. 187-192.

[24] McCrae, R. R., \& John, O. P. (1992). An introduction to the five-factor model and its applications. Journal of Personality, 2, 175-215.

[25] Neuman, W. L. (2007). Basic of Social Research: Qualitative and Quantitative Approaches (2ndedn). New York: Pearson Education, Inc.

[26] Nunnally, J. C., \&Berstein, I. H. (1994). Psychometric Theory. New York: McGraw-Hill.

[27] Olver, J. M., \&Mooradian, T. A. (2003). Personality traits and personal values: a conceptual and empirical integration. Personality and individual differences, 35(1), 109-125. 


\section{American Research Journal of Business and Management, Volume 1, Issue 2, 2015}

ISSN 2379-1047

[28] Ones, D. S., Viswesvaran, C., \&Dilchert, S. (2005). Personality at work: Raising awareness and correcting misconceptions. Human Performance, 18(4), 389-404.

[29] Poggi, A. 2008, "Job satisfaction, working conditions and job-expectations ", LABORatorio R. Revelli, Centre for Employment Studies, LABORatorio R. Revelli Working Papers Series.

[30] Robbin, S.P., (2001). Organizational behavior. New Jersey: Prentice Hall.

[31] SadeghRast., \&AzadehTourani. (2012). Evaluation of Employees' Job Satisfaction and Role of Gender Difference. International Journal of Business and Social Science, Vol. 3 No. 7.

[32] Sekaran, U., \&Bougie, R. (2010). Research methods for business: a skill-building approach (5thed.). Haddington: John Wiley \& Sons.

[33] Staw, B. M., \& Cohen-Charash, Y. (2005). The dispositional approach to job satisfaction: More than a mirage, but not yet an oasis. Journal of Organizational Behaviour, 26(1), 59-78.

[34] SumairaNaz., SumairaRehman., HumairaSaqib. (2013). The relationship between job satisfaction and personality trait among bank employees.Far East Journal of Psychology and Business, Vol. 11 No. 3.

[35] Thompson, E. R., \&Phua, F. T. T. (2012). A Brief Index of Affective Job Satisfaction. Group \& Organization Management 37(3), 275-307.

[36] U.W.M.R. SampathKappagoda. (2012). The impact of five - factor model of personality on job satisfaction of nonacademic employees in sri-lankan universities. South East Asian Journal of Contemporary Business, Economics and Law, Vol. 1ISSN 2289-1560.

[37] Wilkinson, B., (2002) Establishing a Presence, in Marat Terterov and JonathanWallace, doing business with Libya, P.57.

[38] Zeeshan Arshad. (2014). Impact of JDI and Personality Traits on Job Satisfaction. Journal of Business and Management (IOSR-JBM). e-ISSN: 2278-487X, p-ISSN: 2319-7668. 